\title{
Childhood Oligodendroglioma
}

National Cancer Institute

\section{Source}

National Cancer Institute. Childhood Oligodendroglioma. NCI Thesaurus. Code C4045.

An oligodendrog lioma that arises from the central nervous system and occurs during childhood. 